\title{
The Study of Developing and Validating the Union Bias Scale
}

\author{
Ender Kazak (iD) 1,*
}

${ }^{1}$ Düzce University, Faculty of Education, Department of Educational Sciences, Düzce, Turkey

\author{
ARTICLE HISTORY \\ Received: Oct. 20, 2020 \\ Revised: July 21, 2021 \\ Accepted: Oct. 07, 2021 \\ Keywords: \\ Union bias, \\ Ingroup bias, \\ Ingroup favoritism, \\ Outgroup discrimination, \\ Social distance between \\ groups.
}

\begin{abstract}
Observation of different levels and types of organizational problems, such as school principals and teachers suing each other and conflicts between teachers, caused by union bias in schools in Turkey today, is the starting point of this study. This study, therefore, aimed to develop and validate a scale that helps determine union bias in schools. Participants of the study included teachers being a union member and working at a primary, middle or high school in the 2017-2018 and 2018-2019 academic years in Düzce, Turkey. During the data analysis, firstly, the first data set was examined in terms of the assumptions of the factor analysis and then Exploratory Factor Analysis (EFA) was applied. Confirmatory Factor Analysis (CFA) was performed on the second data set. Convergent validity of the scale was examined with item load values, mean-variance, and composite reliability coefficients. Discriminant validity was examined by the Fornell-Lacker criteria. Also, measurement invariance in gender groups was examined. The Cronbach Alpha and combined reliability coefficients were calculated to determine the scale's reliability. The Union Bias scale consists of 27 items and six dimensions. The explained total variance was $64 \%$. As a result of the first and second order confirmatory factor analyses, it was revealed that the six-dimensional structure predicted Union Bias and the scale's structure did not differ in gender groups. The Cronbach's alpha value was .90 and the composite reliability was .96. As a result, the structure of the Union Bias Scale was concluded to be valid and reliable.
\end{abstract}

\section{INTRODUCTION}

The starting point of the study has been the observation of different levels and types of organizational problems between teacher-principal and teacher-teacher led by union bias in some schools in Turkey nowadays. These problems have resulted in several conflicts among teachers, affected school climate negatively, harmed communication climate, and even caused the teachers and principals to sue each other. The reflection of ingroup bias based on the social identity theory on a school comes into existence through union commitment and acts as union bias. Since ingroup bias is a concept generally identified with collectivist cultures, union bias is likely to appear in such cultures. The study may make sense in countries with collectivist cultures such as Turkey, but also the point that dimensions of union bias created due to different reasons, under recent conditions, in countries with individualist cultures may be an object of interest. The study is, therefore, crucial and necessary in terms of finding out the dimensions of

\footnotetext{
*CONTACT: Ender KAZAK \ enderkazak81@hotmail.com Department of Educational Sciences, Düzce, Turkey 
union bias, observing its reflection on organizational environments, and understanding its relationship with organizational variables.

The word "union" is defined as "the unity created together by employees and employers in order to protect and develop their benefits with regard to work, income, social and cultural issues much more" in the Current Turkish Dictionary of the Turkish Language Association (TDK.gov.tr.). Unions started to show up in democratic western countries where the industrial revolution appeared during the first half of the 18th century. Urbanization that came out together with industrialization in the 17 th century led to the rise of a working class having a poor standard of living, low wages, and bad working conditions as well as the emergence of an upper class. A search of voicing their demands in an organized manner to improve working conditions of labors and to provide better life standards generated unions (Güneş, 2013). Union movements in the Western world took place in the wake of a difficult and long period on a social base with the industrial revolution and formed its present-day condition. However, in Turkey, the process of industrialization started late. In the formation of unions in Turkey, a social base or social realities union movements in the West were based on did not appear and the union movements emerged in a factitious way under the government's control (Özkiraz \& Talu, 2008).

In the literature, there have been many theories regarding workers' goals for being a union member. Those theories have been collected under two distinct titles as structural approaches and approaches on individual union membership manner. The former explains changes on the rates of labor union membership based on environmental factors. The latter explains it based on demographic, social, and attitudinal variables and on variables being peculiar to industry and business. Social psychological theories regarding union membership as a process focus on how individuals decide to be a union member. The social psychological theories clarifying the process of being a union member are classified as the frustration-aggression hypothesis, the rational choice theory, the social identity theory, the attribution theory, and interactionist theory (Seçer, 2009). This study is based on the social identity theory and ingroup bias among the social psychological theories clarifying the process of being a union member while union bias is discussed in the context of the social identity theory and ingroup bias.

The aim of education unions is to protect and improve common economic, social, professional, and union rights and benefits of their members and to provide a more prestigious standard of living (Eraslan, 2012). Nonetheless, unfortunately, the primary goal of today's unions is not to protect and improve workers' benefits, but to be a reflection of political and ideological opinions on business life (Özkiraz \& Talu, 2008). In fact, it is a known fact that four confederations organized in the public sector in Turkey and the affiliated unions are mostly close to different long-established political views (Karaman \& Erdoğan, 2016; Kayıkçı, 2013). The reasons why workers become a union member are based not only on economic factors, but also on ideological rationales. Especially, the ideological view is essential in choosing a union to be a member (Bayar, 2015). The ideological dimension implies a unity of values on union commitment between a union and its members. Commitment to union values and principals and reliance on the union are the matters of the ideological dimension. In the dimension, nonutilitarian union ideology is used to achieve union goals being close to their own values and to move collectively. In the utilitarian dimension, a union member makes gain-loss evaluation. There is a relationship in which short-term benefits such as wages, job security, and work safety are prioritized between the union and its members (Sürekli, 1998). On the other hand, teacher unions in ideological conflicts, because of membership and commitment based on ideological dimensions, push their duties on the protection of teachers' social and economic rights and the attainment of new rights into the background (Mert, 2013). That unions have a political view is an intelligible phenomenon, but the perception of education unions as a political organization 
rather than a professional teacher union is a significant obstacle in teacher organizations (Baysal \& Yücel, 2010). Therefore, because of this political perception, teachers stay out of being a union member due to their concerns on alienation (Berkant \& Gül, 2017), grouping, giving a negative impression to school principals, and being treated unfairly in consequence of being a different union member (Arslan, 2015; Demir, 2013; Karaman \& Erdoğan, 2016). As a result, unions' claims to protect their members' rights that affect politics and policymakers could be accepted; nevertheless, union politicization is not a desired situation. This situation may lead to increase in social distance, harming workers' rights as well.

Since ideologically union commitment meets a requirement of a certain collective identity (Sürekli, 1998), being a union member helps workers develop feelings of sense of belonging into a group, collaborating, acting in unison and feeling that they are not alone in their professional lives (Baydar, 2016). The social identity theory advocates that people tend to perceive themselves and others as belonging to several groups because joining a group meets important psychological and social requirements such as belonging, attracting attention, overcoming much more difficult situations, feeling secure, protecting themselves from an outgroup, and having a positive social identity (Kağıtçıbaşı, 2008). According to this theory, people's needs of boosting their self-esteem lead them to better evaluate and glorify the group they get involved in than other groups, while making other groups less significant (Çimendağ, 2013). Obviously, a natural consequence of an understanding on regarding the group they are involved with as precious and the other group as worthless is that people show biased behaviors to the group they get involved with while they demonstrate discriminatory behaviors to the other group, namely the outgroup.

An ingroup is defined as a group of people with a sense of belonging and a shared identity, in other words, a community of "us"; an outgroup is identified as a group of people perceived as distinct and basically different from an ingroup, in other words, a community of "them". The definition of who we are describes who we are not. The circle including "us" (ingroup) excludes "them" (outgroup) (Myers, 2015). Other is an identity of "he/she/it" (outgroup) against "I" personally, and an identity of "they" (outgroup) is against "we" (ingroup) socially. Other is an entity that does not have the characteristics we have. To put it simply, anybody who is not himself/herself is the other (Yurdigül \& İspir, 2015). Ingroup bias is identified as evaluating ingroup members more positively than outgroup members to improve one's self-esteem or stay ahead of the curve in intergroup relations (Çoksan, 2019), shortly as favoring one's own group (Myers, 2015). Ingroup bias is mostly linked with collectivist cultures. In such countries as Turkey, where a collectivist culture is dominant, making a distinction between "we" and "others", unethically, in social and administrative relations leads people in these groups to neglect principals of law and social values, and have an absolute bias against people in their own group or in any events or circumstances. This problem first results in polarization, then in discrimination, and finally in hatred, hostility and conflicts between different labeled identities (Akyürek, 2016). Hostility between groups occurs when an ingroup member shows negative attitudes to members of another group called as outgroup. There are three interrelated but distinguishable components of this kind of group hostility. The first component is that stereotypes, beliefs related to the most common features of group members, are cognitive. The second component is that prejudices, negative emotions towards the target group, are affective. In fact, both stereotypes and prejudices reflect cognitive and affective moods at the same time. The last component is that discrimination, making people at a disadvantage just because they are the other group's members and act upon, is behavioral (Tajfel et al., 1971; Taylor et al., 2007). Evaluating an outgroup based on stereotypes pioneers prejudices as stereotypes enhance specifically the feeling of sympathy within ingroups and discrimination in outgroups (Göregenli, 2012). 
Considering all these ongoing intergroup problems today, the social contact theories offering a solution to these problems become more important (Küçükkömürler \& Sakall1-Uğurlu, 2017). Most studies on intergroup contact have been based on Allport's (1954) study named as "Nature of Prejudice." This theory focuses on the idea that the way to overcome the prejudice is "communication." The intergroup contact theory claims that interpersonal communication between different social group members is one of the most effective ways to promote positive intergroup attitudes (Dovidio et al., 2017; Pettigrew, 2016; Pettigrew \& Tropp, 2006; Seat et al., 2015). The intergroup contact is an essential technique to overcome prejudices, but it requires common goals, equal status, institutional support (support of authority), and mutual close and ongoing contacts based on collaboration in order to be beneficial (Pettigrew, 2016; Taylor et al., 2007). No contact between social groups fosters prejudices, segregation, and social distance but supports discrimination (Çuhadar Gürkaynak, 2012). Discrimination against outgroup members reinforces their commitment to their own group (Keskinkılıç Kara, 2016) and broadens the social distance.

\subsection{The Purpose of the Study}

It is indispensable that workers in the school environment have different beliefs, goals, cultures, and personality characteristics as can be seen in any working environment. The fact that teachers, even if they have a political/social identity, cannot be a member of a political party is stated in the Constitution of the Republic of Turkey. Unions, however, are one of the settings in which this function is partly carried out. Teachers in a union setting are able to discuss on daily political subjects as well as seek the rights of their members; however, the process of politicization has somewhat been continuing in unions. Then, such effects are necessarily reflected on emotions, thoughts, attitudes, and behaviors in organizational environments. These reflections may negatively influence personal relations in these environments and organizational variables such as organizational climate, organizational communication, motivation, etc. by sometimes reinforcing groupings and polarizations. Considering the studies on workers being a union member in Turkey, it is clear that the scales used are about the reasons why workers are a union member, their union commitment and their expectations from a union, and that these subjects have been studied mostly in the context of workers being a union member. However, this paper aims to develop a scale to measure union bias level in the context of ingroup bias unlike the studies in the literature. The developed "union bias scale" is to provide the researchers with an interdisciplinary study enabling them to consider the organizational, educational, and personal effects of union bias thereby helping them to explore the relationship of union bias with organization climate, organizational conflict, organizational cynicism, organizational trust, organizational justice, and communication climate. The scale is designed in order to apply it in all organizational settings including schools as areas of its application. It is also possible to carry out studies in school environments on such issues as political discrimination (Keskinkılıç-Kara, 2016; Keskinkılıç-Kara \& Oguz, 2016), discrimination (Çelik, 2011; Polat \& Hiçyılmaz, 2017), and favoritism (Erdem \& Meriç, 2012; Erdem \& Meriç, 2013; Polat \& Kazak, 2014). It is likely to encounter studies on out-of-school environment like ingroup bias (Çimendağ, 2013; Hasta \& Arslantürk, 2013; Kostakoğlu, 2010; Akyürek, 2016); however, the related literature shows no previous research conducted on investigating ingroup bias and union bias in the context of a school, especially in the national and international literature using the union bias scale. Therefore, the main objective of this study is to fill this gap in the literature by proposing a union bias scale. 


\section{METHOD}

\subsection{Research context and participants}

The study aimed to develop and conduct the "Union Bias Scale" in the context of ingroup bias with its tested reliability and validity. Observation of different levels and types of organizational problems, such as school principals and teachers suing each other and conflicts between teachers, caused by union bias in schools in Turkey was the starting point of the study. Participants included teachers being a union member and working at a primary, middle or high school in Düzce.

The research sample included teachers working at a primary, middle or high school in Düzce Province, Turkey and its seven districts in the 2017-2018 (summer seminar) and 2018-2019 (spring term) academic years. The first implementation of the study was in the summer seminar term in the 2017-2018 academic year, while the second and third implementations were during the fall seminar term and the 2018-2019 academic year. To determine the research sample, the methods of convenience sampling and criterion sampling among non-random sampling methods were used. The criterion was to be a member of any education unions. For this reason, easily accessible schools in the central district and the seven districts of Düzce on the official website of Düzce Provincial Directorate of National Education were listed. The scale was conducted with teachers being a union member, working at those schools and volunteering in filling in the scale. Data was collected from teachers who were the members of the four major unions [Educators' Trade Union (Eğitim Bir Sen), Turkish Education Union (Türk Eğitim Sen), Education and Science Workers' Union (Eğitim İş), and Education and Science Workers' Union (Eğitim Sen)] which had the maximum number of members in Düzce, Turkey. The scale was administered to 272 teachers in the first implementation EFA and to 243 teachers in the second implementation CFA by applying the rule of "being at least five times of the number of item" (Kline, 1994; Tavşancil, 2014) for determining the sample size. The participants for conducting the scale consisted of a total of 329 teachers including 107 (35.52\%) primary school; $145(44.07 \%)$ middle school; and $77(23.40 \%)$ high school teachers. Of all these participants $192(58.35 \%)$ were male and $137(41.64 \%)$ were female teachers. These participants were also composed of 160 (48.63\%) teachers being a member of Eğitim Bir Sen; 106 (32.21\%) teachers being a member of Türk Eğitim Sen; 32 (9.72\%) teachers being a member of Eğitim İş; and 31 $(9.42 \%)$ teachers being a member of Eğitim Sen. Also, $164(49.84 \%)$ of the participants were the members of the same union with their school principals, while $165(50.15 \%)$ of them were not. In terms of their professional seniority, 65 (19.75\%) participants had 1-5 years of professional seniority; 76 (23.10\%) participants were with 6-10 years of professional seniority; $66(20.06 \%)$ participants with 11-15 years of professional seniority; 65 (19.75\%) participants with 16-20 years of professional seniority, and 57 (20.06\%) participants with 21 and above years of professional seniority.

\subsection{The Process of Developing the Scale}

In the process of the development of the Union Bias Scale (UBS), firstly, the literature on ingroup bias and unions/union members were reviewed and then an item pool including 59 items to represent the scale ideally was composed. Significant concepts constituting and determining ingroup bias (ingroup favoritism, outgroup discrimination; ingroup glorification, outgroup disdain; prejudices; stereotypes and social distance between groups) contributed to the development of the dimensions of the UBS. In addition to the literature review, the draft scale was revised by asking for opinions from one active union member teacher from each three different unions and two union representatives in the province, and an item pool was reconstituted with 65 items by adding six more items related to stereotypes between unions. Content validity of the scale was ensured by obtaining expert opinions. Later, opinions of three academicians studying on the subjects of "political discrimination" and "favoritism" and on 
educational science were asked. In the light of the opinions, necessary corrections were made: 12 items that were seen as not being associated with statements, as being unsuitable in terms of meaning and expression, or as being interpreted differently were dropped from the scale. The final draft of the scale consisted of 53 items, which are thought to reflect all of the subdimensions, with a 5-point Likert-type, ranging from "strongly disagree", "disagree", "slightly agree", "quite agree", and "strongly agree". When each grade is expressed verbally, the reliability coefficient is higher when compared to that of the numerical expression (Uyumaz \& Çokluk, 2016). Before conducting the scale, necessary permissions were obtained from the Ministry of National Education, and the scales that the researcher distributed to teachers were gathered by the same researcher within the same day.

\subsection{Data Analysis}

Exploratory factor analysis was applied in order to reveal the factor structure of the scale within the validity study of the Union Bias Scale. First, EFA's assumptions were tested; then, factor analysis was conducted. The parameter estimation bias obtains the lowest value at the maximum likelihood method when the sample is larger than 200 (Uyumaz \& Sirganc1, 2020). Therefore, in this study, maximum likelihood method was preferred for factor extraction because such assumptions were met. Due to the theoretical background of the Union Bias Scale and since its dimensions were considered as related, the direct oblimin method was preferred among oblique rotation methods. In addition, the cut-off value for factor loadings was determined as 0.50 for both AFA and CFA (Hair et al., 2009).

The accuracy of the factor structure of the Union Bias Scale, whose factor structure was revealed with EFA, was tested with CFA over a second data set. The sample used for the development study and the sample used for verification of the scale were different from each other. In other words, a second data set was used to make CFA. This data set consisted of 243 volunteer teachers working in Düzce. Before the CFA, the assumptions of the second data set were tested. To reveal whether the factor structure of the Union Bias Scale was provided or not in the first order; a second-order confirmatory factor analysis was applied to show that the dimensions of the scale came together and represented the variable of Union Bias as a supreme concept. Confirmatory factor analysis was calculated from the covariance matrix and based on the marginal maximum likelihood estimation (MLM) method (Joreskog, 1999). CFA model fit was examined with the factor load values of the items, the variance values they explained, and the model data fit index values. The cut-off value for the factor load value is .50, and the items with a factor load below this value are recommended to be excluded from the scale (Hair et al., 2009). $R^{2}$ is the square of the standardized factor load value of the items and gives the variance ratios explained in the factor of the variable and it is suggested that it should not be less than 0.40 . Model data fit was examined by chi-square $\left(\chi^{2}\right)$, Standardized Root Mean Square Residual (SRMSR), Root Mean Square Error of Approximation (RMSEA), Comparative Fit Index (CFI), and Tucker Lewis Fit Index (TLI) (Brown, 2006).

Convergent validity and discriminant validity were examined after the construct validity studies. Convergent validity is the evaluation made to measure the correlation level of more than one indicator/item of the same structure that is in harmony. To ensure convergent validity, item factor load values should be $\geq 0.5$ (Hair, et al., 2009), average variance extracted (AVE) value should be 0.5 , and construct reliability values should be 0.7 (Fornell \& Larcker, 1981). Discriminant validity refers to the degree to which the structure is empirically different from each other. It also measures the degree of differences between overlapping structures (Hair et al., 2014). In this study, the discriminant validity was examined with the Fornell-Lacker criterion (Fornell \& Larcker, 1981). This method compares the square root of the average variance extracted (AVE) with the correlation of latent structures. A latent structure should better explain the variance of its own indicator rather than the variance of other latent structures. 
Therefore, the square root of the AVE of each structure must have a greater value than the correlations with other latent structures (Hair et al., 2014).

In this study, measurement invariance in gender groups was examined as another validity proof. Measurement invariance is that the relationship between observed variables (items) and latent variables (measured structure) is the same between the examined subgroups (Widaman \& Reise, 1997). In this study, measurement invariance between gender groups was tested with multi-group CFA. Besides, the statistical significance of the difference between the loads and interceptors of the items estimated according to gender groups with the alignment method was examined (Asparouhov \& Muthén, 2014).

The most common measurements used for internal consistency are Cronbach alpha and composite reliability; they measure reliability based on the interrelationship of observed item variables. The values range from 0 to 1 . A higher value indicates a higher reliability level. In exploratory research, the values of composite reliability/Cronbach alpha between 0.60 to 0.70 are acceptable, while in a higher stage the value has to be higher than 0.70 (Hair et al., 2014). However, the value that is more than 0.90 is not desirable and the value that is 0.95 or above is undesirable (Nunnally \& Bernstein, 1994). Indicator reliability is the proportion of indicator variance explained by the latent variable. The values range from 0 to 1 . The outer loadings value should be higher than 0.70 and it should be considered for deletion if the removal of the indicator with outer loadings which is between 0.40 and 0.70 and if it contributes to an increase in composite reliability and average variance extracted (Hair et al., 2014).

Hypothesis tests and exploratory factor analysis were performed with SPSS 20.0 and confirmatory factor analysis and multi-group confirmatory factor analysis were performed with Mplus 7.3. The explained average variance (AVE) and composite reliability (CR) were calculated in an Excel program using the formulas as suggested by Fornell and Larcker (1981).

\section{FINDINGS}

\subsection{Findings Regarding the Validity of the Union Bias Scale}

\subsubsection{Exploratory factor analysis (EFA)}

The factor structure of the Union Bias Scale was determined by the exploratory factor analysis applied to the data set collected from the first sample. Before the exploratory factor analysis was applied, the data set was tested in terms of the assumptions of the factor analysis, such as missing value, one-way and multivariate extreme value, univariate and multivariate normality, multicollinearity, and singularity. One-sided extreme values were examined by converting the item scores of the scale to the standard $\mathrm{z}$ score (Tabachnick \& Fidel, 2007) and all of the standard scores that were outside the score range were removed from the 4 observation data sets of $\pm 4 \mathrm{z}$ (Mertler \& Vannata, 2005). Mahalanobis Distances (MU) were calculated for multivariate extreme value analysis and 19 MU values were extracted from observation data sets that exceeded $\alpha=0.001$ and critical $=90.57$ in 53 degrees of freedom (Tabachnick \& Fidell, 2007). The skewness coefficients of the items varied between -1.816 and 2.658 and the kurtosis coefficients varied between -1.592 and 6.593. Chou and Bentler (1995) stated that the assumption of univariate normality is fulfilled as long as the coefficient of skewness is 3 and Kline (2005) stated that the assumption of univariate normality is fulfilled as long as the kurtosis coefficient does not exceed 10. Therefore, it is seen that the assumption of univariate normality is provided. Since the scatter plot (Figure 1) formed by squared Mahalanobis distance values ( $m_{i}{ }^{2}$ ) and inverse cumulative chi-square values show a linear structure, the assumption of multivariate normality is achieved (Alpar, 2011).

For multicollinearity, the dual correlations of the items were examined and no correlation value exceeding the critical value of $r=0.85$ was found (Kline, 2005). The factor analysis was 
performed by removing 5 items (1-33-35-36-40) with item-total correlations below .30 from the data set (Nunnally \& Bersntein, 1994).

Figure 1. Multivariate Normality.

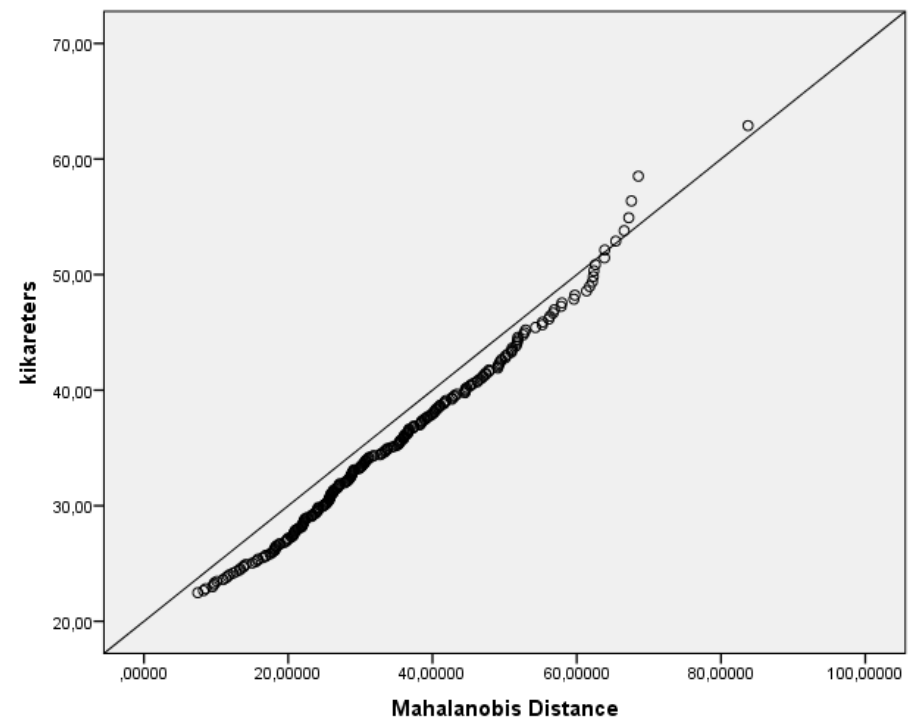

As a result of testing the assumptions, 23 observations were extracted from the first sample consisting of 272 observations and EFA was applied to the data set of 249 people consisting of 48 items. Kline (2005) stated that a sample of 200 people is sufficient for factor analysis. The suitability of the data set related to the Union Bias Scale to the exploratory factor analysis was examined by Kaiser-Meyer-Olkin (KMO) and Bartlett tests. The KMO value approaching 1 means that each variable in the scale can be predicted by other variables and 0.60 and above is sufficient for social sciences (Kline, 2005). In this study, the KMO value was calculated as 0.92. When Bartlett test results are examined, it is seen that the value obtained as $\chi^{2}$ $=8889.412 ; s d=1128(p=0.000)$ is significant at the 0.01 level. Therefore, it was concluded that the correlation matrix is different from the identity matrix. According to the KMO value and Bartlett test results, it was concluded that the data matrix of the Union Bias Scale consisting of 48 items is suitable for factor analysis.

In factor analysis, factor extraction was performed by using Direct Oblimin, maximum likelihood method, rotation, and oblique rotation techniques. To decide whether the items would be removed in EFA, the minimum level of factor loading was accepted as .30 (Tabachnick \& Fidell, 2001). As a result of EFA, 27 out of 48 items in the item pool were grouped under six factors/dimensions, whose eigenvalues were greater than 1.0.21 items (items $2,6,7,9,10,11,12,13,14,15,16,23,24,31,32,34,39,41,43,45,53)$ that did not load on any factor, whose item factor loading was smaller than .30 and loaded under more than one factor and the difference between the load values less than 0.10 were eliminated from the analysis. The removal of items was performed one by one and the analysis was repeated after each removed item. As a result of the repeated factor analysis, a 6-factor/dimensional structure with an eigenvalue above 1.00 was observed. The scree plot given in Figure 2 also shows that the items can be collected under six dimensions. 
Figure 2. Scree Plot.

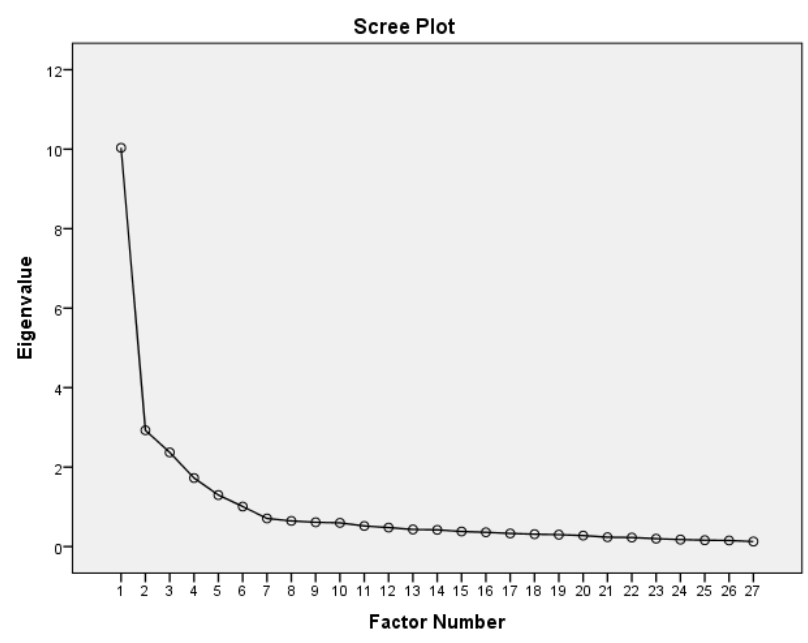

In Table 1, factor load values of 27 items remaining after EFA are given. The factor loadings of the remaining 27 items before being subjected to rotation were found to be 0.349 and 0.737 . After the oblique rotation technique was applied, it was observed that factor load values varied between 0.472 and 0.891 . Table 1 shows that the scale was composed of the first dimension with 3 items (factor loadings between 0.56 and 0.88 ); the second dimension with 5 items (factor loadings between 0.52 and 0.89); the third dimension with 6 items (factor loadings between 0.62 and 0.86 ); the fourth dimension with 5 items (factor loadings between 0.47 and 0.87 ); the fifth dimension with 4 items (factor loadings between 0.51 and 0.83 ); and the sixth dimension with 4 items (factor loadings between 0.52 and 0.89 ). It was found out that all factors explained $64.30 \%$ of the total variance: the first factor explained $35.60 \%$; the second explained $8.64 \%$; the third explained $7.90 \%$; the fourth explained 5.47\%; the fifth explained 3.87\%; and the sixth explained $2.73 \%$ of the total variance. The explained variance ratios were found enough to be $30 \%$ in scales with one factor and to have ranged between $40 \%$ and $60 \%$ in scales with multifactors (Büyüköztürk, 2006; Tavşancıl, 2014). Accordingly, the explained variance ratio was adequate.

Table 1. Item Load Values of the Union Bias Scale.

\begin{tabular}{lllllll}
\hline Item/Dimension & $\begin{array}{l}\text { Social } \\
\text { Distance }\end{array}$ & Stereotypes & $\begin{array}{l}\text { In Group } \\
\text { Glorification }\end{array}$ & $\begin{array}{l}\text { Out } \\
\text { Group } \\
\text { Disdain }\end{array}$ & $\begin{array}{l}\text { In Group } \\
\text { Favoritism }\end{array}$ & Prejudices \\
\hline Item 38 & .879 & .040 & -.084 & .054 & .000 & .021 \\
Item 37 & .868 & .042 & -.115 & -.005 & -.023 & .026 \\
Item 30 & .565 & .057 & .013 & .059 & .195 & .087 \\
Item 50 & -.075 & .890 & -.020 & .016 & .007 & .023 \\
Item 49 & .054 & .777 & .025 & .049 & -.046 & -.022 \\
Item 52 & -.048 & .777 & -.019 & .063 & -.045 & .037 \\
Item 51 & .182 & .653 & .079 & -.095 & .197 & .000 \\
Item 48 & -.036 & .525 & -.208 & .061 & -.092 & .082 \\
Item 26 & -.003 & .008 & -.862 & .018 & -.038 & .055 \\
Item 27 & -.010 & -.015 & -.807 & .119 & .022 & .039 \\
Item 25 & .164 & .009 & -.802 & .056 & -.035 & .004 \\
Item 22 & .198 & .045 & -.692 & .016 & .046 & .010 \\
Item 29 & -.081 & .073 & -.660 & .013 & .067 & -.030 \\
Item 28 & -.015 & -.041 & -.622 & -.058 & .147 & -.007 \\
Item 19 & .011 & .008 & -.048 & .875 & -.032 & .009 \\
Item 18 & -.027 & .027 & .022 & .839 & .093 & -.037 \\
\hline
\end{tabular}


Table 1. Continues.

\begin{tabular}{lccccll}
\hline Item 21 & -.044 & .162 & -.046 & .613 & .074 & .115 \\
Item 17 & .088 & -.080 & -.212 & .495 & .015 & .160 \\
Item 20 & .323 & -.022 & .049 & .472 & .143 & .062 \\
Item 4 & -.033 & -.008 & -.073 & .028 & .834 & -.019 \\
Item 5 & -.017 & .017 & -.001 & .085 & .832 & -.011 \\
Item 3 & .085 & -.005 & -.073 & -.043 & .678 & .101 \\
Item 8 & .028 & .017 & -.132 & .148 & .515 & .056 \\
Item 46 & .031 & -.004 & -.013 & -.030 & .010 & .891 \\
Item 44 & -.079 & .014 & -.095 & -.017 & .025 & .793 \\
Item 42 & .260 & -.108 & .066 & .033 & .091 & .532 \\
Item 47 & -.029 & .130 & .057 & .109 & -.028 & .519 \\
\hline Eigenvalue & 4.690 & 4.004 & 6.304 & 6.202 & 5.712 & 5.537 \\
Explained & 35.60 & 8.64 & 7.99 & 5.48 & 3.89 & 2.73 \\
Variance & & & & & & \\
Cumulative & 35.60 & 44.24 & 52.22 & 57.70 & 61.57 & 64.30 \\
Variance & & & & & & \\
\hline
\end{tabular}

Note. Factor load values of 0.20 and above are presented in the table.

When the items in the dimensions are examined, it is seen that there is a factorization consistent with the literature. Accordingly, since the items in the first dimension are Social Distance (SD), the items in the second dimension are Stereotypes (S), the items in the third dimension are In Group Glorification (IGG), the items in the fourth dimension are Out Group Disdain (OGD), the items in the fifth dimension are In Group Favoritism (IGF), and the items in the sixth dimension are related to Prejudices $(\mathrm{P})$; the factors are named accordingly. The correlation coefficients between the dimensions of the scale are given in Table 2. It is seen that the correlation coefficients between dimensions change between 0.20 and 0.60 . It has been revealed that the dimensions are in a positive, meaningful, and moderate relationship with each other.

Table 2. Correlation Coefficients between Factors.

\begin{tabular}{lllllll}
\hline & SD & S & IGG & OGD & IGF & P \\
\hline SD & 1 & $.569^{* *}$ & $.568^{* *}$ & $.600^{* *}$ & $.399^{* *}$ & $.196^{* *}$ \\
S & & 1 & $.531^{* *}$ & $.465^{* *}$ & $.545^{* *}$ & $.352^{* *}$ \\
IGG & & & 1 & $.370^{* *}$ & $.275^{* *}$ & $.251^{* *}$ \\
OGD & & & & 1 & $.453^{* *}$ & $.244^{* *}$ \\
IGF & & & & & 1 & $.327^{* *}$ \\
P & & & & & & 1 \\
\hline
\end{tabular}

$* * p<.01$

\subsubsection{Confirmatory factor analysis (CFA)}

A second-order confirmatory factor analysis was conducted because the important concepts associated with ingroup bias (ingroup favoritism, outgroup discrimination; in-group glorification, outgroup disdain; prejudices; stereotypes and social distance between groups) contributed to forming the dimensions of union bias (Allport, 1954; Myers, 2015; Pettigrew \& Tropp, 2006; Tajfel et al., 1971; Taylor et al., 2007). For the one-way outlier analysis, the items of the scale were converted to the standard $\mathrm{z}$ score, and 10 observations outside the $\pm 4 \mathrm{z}$ score range (Mertler \& Vannata, 2005) were removed from the data set. For the versatile extreme value analysis, Mahalanobis Distances (MD) were calculated and 13 observations whose MD values exceeded $\alpha=0.001$ and 27 degrees of freedom exceeding the critical value of $\chi^{2}=55.48$ were removed from the data set (Tabachnick \& Fidell, 2007). The skewness coefficients of the items varied between 0.609 and 1.336 and the kurtosis coefficients varied between -1.090 and 
5.840. Since the coefficient of skewness $|3|$ (Chou \& Bentler, 1995) does not exceed the kurtosis coefficient $|10|$ (Kline, 2005), it has been determined that the assumption of univariate normality is provided. The scatter plot (Figure 3 ) formed by squared Mahalanobis distance values $\left(\mathrm{M}_{\mathrm{i}}{ }^{2}\right)$ and inverse cumulative chi-square values show a structure close to the linear. Therefore, it can be said that the assumption of multivariate normality is also provided.

Figure 3. Multivariate Normality.

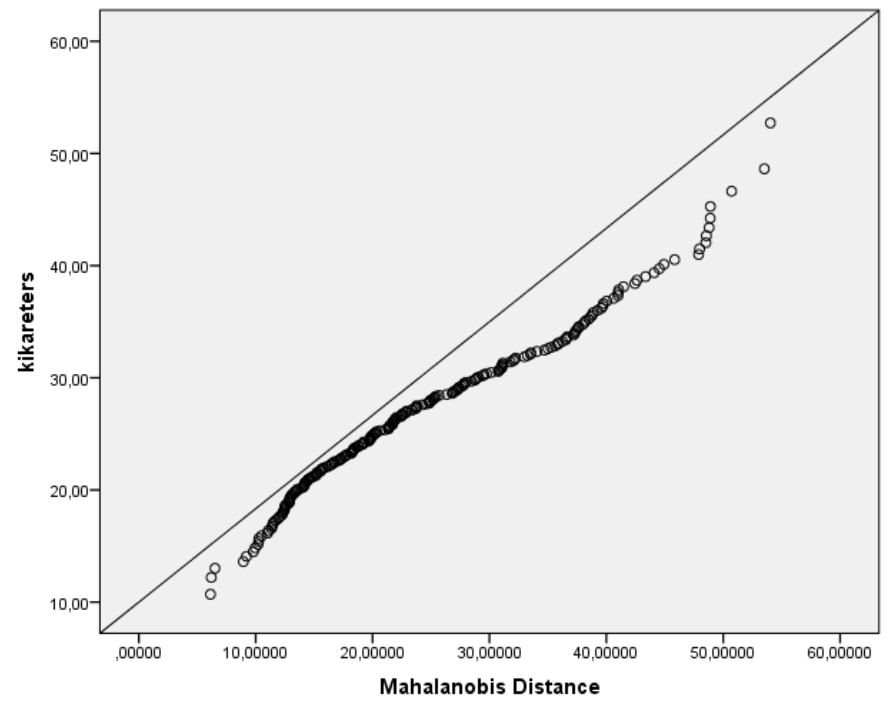

For multicollinearity, the binary correlations of the items were examined and no correlation value exceeding the critical value of $\mathrm{r}=0.85$ was found (Kline, 2005). In Table 3, the standardized factor load $\left(\lambda_{\mathrm{i}}\right)$ obtained as a result of the first and second-order confirmatory factor analysis of the six-dimensional structure of the Union Bias Scale and the variance $\left(\mathrm{R}^{2}\right)$ explained by the items and the goodness of fit values are given. Besides, the diagrams for first and second-order factor analysis are presented in Figures $4 \mathrm{a}$ and $4 \mathrm{~b}$, respectively. Standardized factor loadings show the contribution of the item/indicator to the relevant factor. Accordingly, the factor loads of the items in the "In Group Favoritism" dimension ranged between 0.61 and 0.87; between 0.58 and 0.84 in the "Out Group Disdain" dimension; between 0.60 and 0.84 in the "In Group Glorification" dimension; between 0.62 and 0.83 in "Social Distance" dimension; between 0.64 and 0.81 in the "Prejudices" dimension; between 0.55 and 0.90 in "Stereotypes" dimension, and these values are higher than 0.5 specified as the acceptable factor load (Hair et al., 2009). When the variance values explained by the items were examined, it was seen that the acceptance value of six items was below 0.40 . Since the variance values explained by these items were very close to the limit value, the model was examined together with the goodness of fit and item reliability index values and it was decided to keep the items in the scale. When the goodness of fit indexes regarding the first order CFA were evaluated, the rate of $\chi^{2} / s d$ was found to be $1.60\left(\chi^{2} / s d=493.870 / 309\right)$. When this value is $0<\chi^{2} / s d<3$, it shows a perfect consistency (Schermelleh-Engel, Moosbrugger \& Müller, 2003). It was found that the value of RMSEA was .052, Comparative Fit Index (CFI) was .97, Tucker Lewis Index (TLI) was 0.91, and Standardized Root Mean Square Residual (SRMR) was 0.063. In the literature, acceptable limit values for the goodness of fit values are in the range of 0.90-1.00 for CFI and TLI values (Bentler \& Bonnet, 1980; Tucker \& Lewis, 1973); for RMSEA and SRMR values, it is reported that the lower limit should be 0 and the upper limit should be 0.08 (Hooper, Coughlan, \& Mullen, 2008). When the findings are evaluated together, it is seen that the six-factor structure of the Union Bias Scale revealed by EFA is confirmed by CFA. 
A second-order confirmatory factor analysis was conducted to show that the dimensions of "In Group Favoritism", "Out Group Disdain", "In Group Glorification", "Social Distance", "Prejudices", and "Stereotypes", which were obtained with the first-order confirmatory factor analysis of the Union Bias Scale, come together, and represent the higher dimension of the Union Bias variable (Büyüköztürk, 2002). The relationships between the latent variables obtained in the first-order factor analysis were used as the basis for the model examined. The variances explained by the bias variable in the first-order variables were revealed by the analysis. The factorial model of the second-order CFA result is presented in Figure $4 \mathrm{~b}$ and the standardized factor load values and explained variance values regarding the factor-item relationship are presented in Table 3 . The results of testing the second-order factor model by adding the second-order "bias" latent variable to the first-order confirmatory structure tested with six latent and 27 indicator variables showed that the goodness of fit values were: $\chi^{2} / d f=$ $1.65(523.589 / 318), \mathrm{CFI}=0.91, \mathrm{TLI}=0.90, \mathrm{RMSEA}=0.056$, and $\mathrm{SRMR}=0.076$. These values reveal that the data show an acceptable fit.

Table 3. Standardized Factor Loads $\left(\lambda_{i}\right)$ of the Items of Union Bias Scale and Explained Variance $\left(\mathrm{R}^{2}\right)$ Values.

\begin{tabular}{|c|c|c|c|c|c|}
\hline \multirow[b]{2}{*}{ Factor } & \multirow[b]{2}{*}{ Item } & \multicolumn{2}{|c|}{ First Order } & \multicolumn{2}{|c|}{ Second Order } \\
\hline & & $\left(\lambda_{j}\right)$ & $\mathrm{R}^{2}$ & $(\lambda \mathrm{i})$ & $\mathrm{R}^{2}$ \\
\hline \multirow{4}{*}{ IGF } & Item 3 (y1) & 0.630 & 0.40 & 0.630 & 0.40 \\
\hline & Item 4 (y2) & 0.874 & 0.76 & 0.873 & 0.76 \\
\hline & Item 5 (y3) & 0.800 & 0.64 & 0.803 & 0.64 \\
\hline & Item $8(\mathrm{y} 4)$ & 0.606 & 0.37 & 0.605 & 0.37 \\
\hline \multirow{5}{*}{ OGD } & Item 17 (y5) & 0.582 & 0.34 & 0.582 & 0.34 \\
\hline & Item 18 (y6) & 0.784 & 0.61 & 0.783 & 0.61 \\
\hline & Item 19 (y7) & 0.839 & 0.70 & 0.839 & 0.70 \\
\hline & Item 20 (y8) & 0.666 & 0.44 & 0.670 & 0.45 \\
\hline & Item 21 (y9) & 0.806 & 0.65 & 0.805 & 0.65 \\
\hline \multirow{6}{*}{ IGY } & Item $22(\mathrm{y} 10)$ & 0.753 & 0.57 & 0.756 & 0.57 \\
\hline & Item $25(\mathrm{y} 11)$ & 0.843 & 0.71 & 0.849 & 0.72 \\
\hline & Item $26(\mathrm{y} 12)$ & 0.772 & 0.59 & 0.775 & 0.60 \\
\hline & Item 27 (y13) & 0.775 & 0.60 & 0.770 & 0.59 \\
\hline & Item 28 (y14) & 0.596 & 0.36 & 0.585 & 0.34 \\
\hline & Item $29(\mathrm{y} 15)$ & 0.609 & 0.37 & 0.603 & 0.36 \\
\hline \multirow{3}{*}{ SD } & Item $30(\mathrm{y} 16)$ & 0.622 & 0.39 & 0.627 & 0.39 \\
\hline & Item 37 (y17) & 0.834 & 0.70 & 0.824 & 0.68 \\
\hline & Item $38(\mathrm{y} 18)$ & 0.786 & 0.62 & 0.793 & 0.63 \\
\hline \multirow{4}{*}{$\mathrm{P}$} & Item 42 (y19) & 0.636 & 0.40 & 0.622 & 0.39 \\
\hline & Item $44(\mathrm{y} 20)$ & 0.777 & 0.60 & 0.782 & 0.61 \\
\hline & Item $46(\mathrm{y} 21)$ & 0.813 & 0.66 & 0.821 & 0.67 \\
\hline & Item 47 (y22) & 0.583 & 0.34 & 0.577 & 0.33 \\
\hline \multirow{5}{*}{ KYG } & Item $48(y 23)$ & 0.588 & 0.35 & 0.584 & 0.34 \\
\hline & Item $49(\mathrm{y} 24)$ & 0.667 & 0.44 & 0.667 & 0.44 \\
\hline & Item $50(\mathrm{y} 25)$ & 0.905 & 0.82 & 0.901 & 0.81 \\
\hline & Item $51(\mathrm{y} 26)$ & 0.553 & 0.30 & 0.559 & 0.31 \\
\hline & Item $52(\mathrm{y} 27)$ & 0.702 & 0.49 & 0.707 & 0.500 \\
\hline Goodness of Fit Values & $\begin{array}{lll}X^{2} & s d & X^{2} / s d\end{array}$ & CFI & TLI & RMSEA & SRMR \\
\hline First Order & $\begin{array}{lll}493.870 & 309 & 1.60\end{array}$ & 0.92 & 0.91 & 0.052 & 0.063 \\
\hline Second Order & $\begin{array}{lll}523.589 & 318 & 1.65\end{array}$ & 0.91 & 0.90 & 0.054 & 0.076 \\
\hline
\end{tabular}


The factor loadings between the first-order latent variables in the model and the higher level (second-order) variable and the explanation ratios of the second-order variable in the first-order variables $\left(\mathrm{R}^{2}\right)$ are presented in Table 4 .

Table 4. Second Order CFA Standardized Factor Load and Explained Variance Values.

\begin{tabular}{llll}
\hline Second Order Variable & First Order Variable & $\lambda$ & $\mathrm{R}^{2}$ \\
\hline \multirow{4}{*}{ Union Bias } & IGF & 0.524 & 0.275 \\
& OGD & 0.853 & 0.727 \\
& IGG & 0.582 & 0.339 \\
& SD & 0.412 & 0.169 \\
& P & 0.848 & 0.719 \\
& S & 0.359 & 0.129 \\
\hline
\end{tabular}

Figure 4b. Second-Order CFA
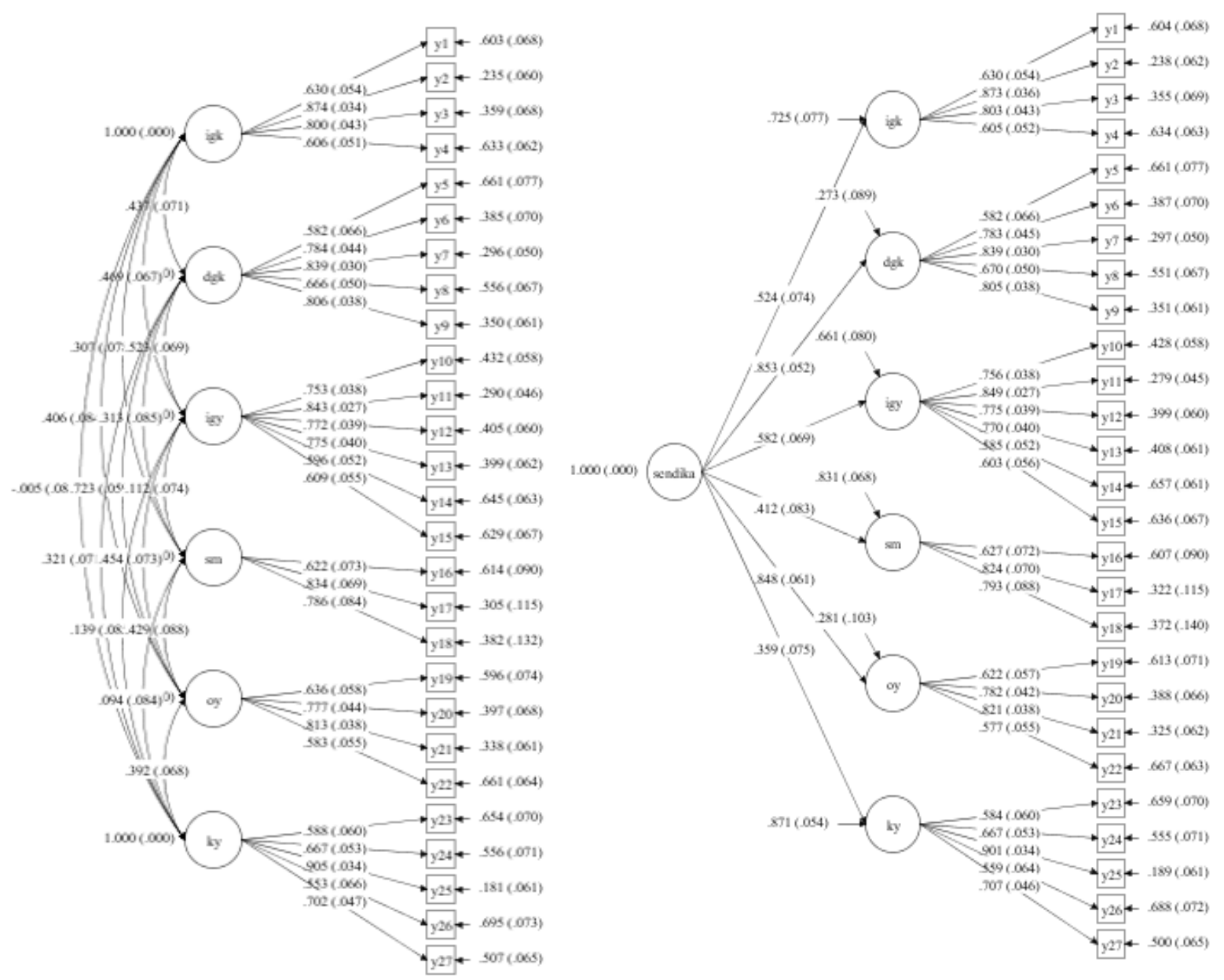

When Figure $4 \mathrm{~b}$ and Table 4 are evaluated together, the strongest relationship between the latent variable "union bias" and the first-order latent variables is seen in union bias and the Out Group Disdain and Prejudice factors, and the weakest relationship is seen with the factors of Social Distance and Stereotypes. Looking at the variances explained by the second-order variable in the first-order variables, among the first-order variables, the most variability was explained in the Out Group Disdain and Prejudice factors, and the least variability was explained in the Social Distance and Stereotypes factors.

As is displayed in Table 5, the correlation coefficients between the scores obtained from all the items and the scores obtained from the factors and the scale were calculated and the 
discrimination rate of each item was determined to reveal the extent to which each item served the general purpose of the factor. For this, item subscale correlations, item-test correlations, and alpha reliability of the scale were reported when each item was deleted.

Item-total correlations ranged between $0.52-0.76$ in In Group Favoritism; between 0.54-0.77 in Out Group Disdain; between 0.57-0.75 in In Group Glorification; between 0.55-0.69 In Social Distance; between 0.52-0.70 in Prejudices; and between 0.49-0.77 in Stereotypes. When the item-test correlation coefficients for the whole scale were examined, the lowest correlation value was found to be 0.25 and the highest correlation was found to be 0.67 . Each item had a significant and positive relationship with the overall scale $(p<0.001)$. The acceptable value for item-total correlations is around 0.20 (Kalayc1, 2010). Since there was no significant increase in alpha reliability when the item with the lowest correlation value was removed from the scale, it was decided to keep this item in the scale. These coefficients are validity coefficients for the discrimination of all items, and they show consistency of the items both with their dimensions and with the whole scale. When the alpha reliability values given in the last column are examined, it can be said that each item contributes at similar levels to the whole scale.

Table 5. Item-Total Correlations on the Basis of Dimensions and Scales.

\begin{tabular}{|c|c|c|c|c|c|}
\hline Dimensions & Items & $\begin{array}{l}\text { Item-Subscale } \\
\text { Correlation }\end{array}$ & $\begin{array}{l}\text { Alpha if Item } \\
\text { Deleted }\end{array}$ & $\begin{array}{l}\text { Item-Test } \\
\text { Correlation }\end{array}$ & $\begin{array}{l}\text { Alpha if Item } \\
\text { Deleted }\end{array}$ \\
\hline \multirow{4}{*}{ IGF } & Item 3 (y1) & .549 & .793 & .408 & .888 \\
\hline & Item 4 (y2) & .757 & .688 & .462 & .887 \\
\hline & Item 5 (y3) & .694 & .724 & .446 & .887 \\
\hline & Item $8(\mathrm{y} 4)$ & .525 & .813 & .482 & .887 \\
\hline \multirow{5}{*}{ OGD } & Item 17 (y5) & .538 & .851 & .526 & .886 \\
\hline & Item $18(\mathrm{y} 6)$ & .707 & .811 & .669 & .882 \\
\hline & Item $19(\mathrm{y} 7)$ & .773 & .790 & .619 & .883 \\
\hline & Item 20 (y8) & .614 & .837 & .525 & .886 \\
\hline & Item 21 (y9) & .717 & .806 & .625 & .883 \\
\hline \multirow{6}{*}{ IGG } & Item $22(\mathrm{y} 10)$ & .672 & .844 & .530 & .886 \\
\hline & Item $25(\mathrm{y} 11)$ & .753 & .829 & .548 & .885 \\
\hline & Item 26 (y12) & .724 & .834 & .478 & .887 \\
\hline & Item 27 (y13) & .695 & .839 & .619 & .883 \\
\hline & Item 28 (y14) & .566 & .864 & .394 & .889 \\
\hline & Item $29(\mathrm{y} 15)$ & .596 & .856 & .380 & .889 \\
\hline \multirow{3}{*}{ SD } & Item $30(\mathrm{y} 16)$ & .553 & .778 & .287 & .890 \\
\hline & Item 37 (y17) & .688 & .645 & .297 & .890 \\
\hline & Item 38 (y18) & .655 & .685 & .338 & .889 \\
\hline \multirow{4}{*}{$\mathrm{P}$} & Item 42 (y19) & .520 & .768 & .508 & .886 \\
\hline & Item $44(y 20)$ & .655 & .698 & .598 & .884 \\
\hline & Item $46(\mathrm{y} 21)$ & .703 & .676 & .588 & .884 \\
\hline & Item $47(\mathrm{y} 22)$ & .517 & .777 & .476 & .887 \\
\hline \multirow{5}{*}{ S } & Item 48 (y23) & .491 & .802 & .253 & .893 \\
\hline & Item $49(\mathrm{y} 24)$ & .597 & .770 & .280 & .892 \\
\hline & Item $50(\mathrm{y} 25)$ & .770 & .718 & .385 & .889 \\
\hline & Item $51(\mathrm{y} 26)$ & .514 & .795 & .287 & .892 \\
\hline & Item 52 (y27) & .621 & .763 & .402 & .888 \\
\hline
\end{tabular}




\subsubsection{Convergent Validity}

The convergent validity of the scale was examined by considering item factor loads, inferred mean-variance, and combined reliability. It is seen that item factor loads presented in Table 3 have a cut-off value above 0.5 in both first and second order CFA (Hair et al., 2009). The average variance and combined reliability values obtained are presented in Table 9. Accordingly, the average variance value extracted from the whole scale and its dimensions are above 0.5 . The average variance extracted (AVE) value for only the stereotypes dimension was 0.48 . The average variance extracted value extracted only in the stereotypes dimension was found to be 0.48 . Fornell and Larcker (1981) stated that the convergent validity of the construct is still sufficient if the mean-variance is less than 0.5 , but the composite reliability is higher than 0.6. Therefore, it can be said that this dimension also has convergent validity. Besides, it is seen that the structural reliability values (combined reliability and Cronbach alpha) are higher than 0.7 (Fornell \& Larcker, 1981) in all dimensions and the entire scale. When all findings are evaluated together, it is seen that the convergent validity of the Union Bias Scale is provided.

\subsubsection{Discriminant Validity}

In this study, the differential validity was examined by comparing the square root of the meanvariance (AVE) and the correlation of latent structures. Factors are considered to be discriminatory when the square root of AVE values is greater than the correlations between latent variables (Fornell \& Larcker, 1981). In Table 6, it is seen that the average variance inferred by each dimension is higher than the relationships between dimensions. Therefore, it was revealed that the discriminative validity of the scale was also provided.

Table 6. Discriminant Validity Findings.

\begin{tabular}{lllllll}
\hline & IGF & OGD & IGG & SD & P & S \\
\hline IGF & 0.735 & $.569^{* *}$ & $.568^{* *}$ & $.600^{* *}$ & $.399^{* *}$ & $.196^{* *}$ \\
OGD & & 0.742 & $.531^{* *}$ & $.465^{* *}$ & $.545^{* *}$ & $.352^{* *}$ \\
IGG & & & 0.728 & $.370^{* *}$ & $.275^{* *}$ & $.251^{* *}$ \\
SD & & & & 0.756 & $.453^{* *}$ & $.244^{* *}$ \\
P & & & & & 0.707 & $.327^{* *}$ \\
S & & & & & & 0.693 \\
${ }^{* *} p<.01$ & & & & & &
\end{tabular}

\subsubsection{Measurement Invariance}

In this study, the multi-group CFA (WG-CFA) analysis was conducted to test whether the factor structure of the Union Bias Scale differentiated in gender groups. Besides, with the alignment method, it was examined whether the difference between the factor load and intercept values of each item was statistically significant or not. Table 7 includes the findings of WG-CFA. Sokolov (2019) suggested considering the CFI value of measurement invariance with WG-DFA and stated that the relative goodness of fit should be CFI $<-0.01$ to ensure weak invariance and strong invariance as cut-off values. Accordingly, when Table 7 is examined, it is seen that strong invariance with weak invariance in all dimensions is very close to the limit value. Also, gradually, it is seen that the chi-square difference between models is not statistically significant. Weak invariance is based on the assumption that factor loads between groups are equal. Thus, factor variances and structural relationships between groups are comparable. When the results are evaluated together, it can be said that the factor loads of the Union Bias Scale are equal between gender groups. In the Social Distance dimension, fit index values for the structural model were not produced. This is thought to be due to the number of items.

Table 8 includes the findings regarding the factor load and intercept of each item and the statistical significance of their differences in gender groups. 
Table 7. Findings of Multi-Group CFA Analysis.

\begin{tabular}{lllllll}
\hline & Model & $\chi^{2}$ & $d f$ & $p$ & CFI $^{*}$ & $\Delta$ CFI \\
\hline \multirow{2}{*}{ GGF } & Weak-Structural & 3.391 & 3 & 0.3352 & 0.974 & -0.001 \\
& Strong-Structural & 11.344 & 6 & 0.0783 & 0.973 & -0.018 \\
& Strong-Weak & 7.954 & 3 & 0.0470 & 0.956 & -0.017 \\
\hline \multirow{2}{*}{ OGD } & Weak-Structural & 6.327 & 4 & 0.1760 & 0.950 & -0.006 \\
& Strong-Structural & 13.386 & 8 & 0.0992 & 0.944 & -0.013 \\
& Strong-Weak & 7.059 & 4 & 0.1338 & 0.937 & -0.007 \\
\hline IGG & Weak-Structural & 6.029 & 5 & 0.3034 & 0.942 & -0.001 \\
& Strong-Structural & 12.675 & 10 & 0.2424 & 0.941 & -0.003 \\
& Strong-Weak & 6.646 & 5 & 0.2483 & 0.939 & -0.002 \\
\hline P & Weak-Structural & 4.843 & 3 & 0.1836 & 0.945 & -0.005 \\
& Strong-Structural & 12.068 & 6 & 0.0605 & 0.940 & -0.017 \\
& Strong-Weak & 7.225 & 3 & 0.0651 & 0.928 & -0.012 \\
\hline S & Weak-Structural & 4.495 & 4 & 0.3431 & 0.982 & -0.001 \\
& Strong-Structural & 14.650 & 8 & 0.0663 & 0.981 & -0.018 \\
& Strong-Weak & 10.154 & 4 & 0.0379 & 0.964 & -0.017 \\
\hline
\end{tabular}

*CFI values are presented in order of structural, weak and strong invariance.

The results of the alignment analysis show that there is no statistically significant difference between the factor loads and intercepts of all items except the y19 coded item. Therefore, this result shows that strong invariance is provided, which assumes that both factor loadings and intercepts are invariant between gender groups. Therefore, it is possible to compare factor averages and intercepts between gender groups. The cut-off value of the y19 coded item in gender groups did not differ significantly, but the load value varied. Accordingly, it can be said that while weak invariance is provided in this item, strong invariance is not provided. As a result, it can be said that all the items of the Union Bias Scale are invariant for men and women.

Table 8. Test of Significance of Item Loadings and Intercepts Between Gender Groups.

\begin{tabular}{|c|c|c|c|c|c|c|c|c|c|}
\hline & & & & & Value 1 & Value 2 & Difference & $\mathrm{SE}$ & $\mathrm{P}$-value \\
\hline \multirow{8}{*}{ IGF } & \multirow{4}{*}{ Intercept } & Item 3 (y1) & 2 & 1 & 1.455 & 1.462 & -0.007 & 0.043 & 0.873 \\
\hline & & Item 4 (y2) & 2 & 1 & 1.887 & 1.808 & 0.079 & 0.185 & 0.672 \\
\hline & & Item 5 (y3) & 2 & 1 & 1.727 & 1.713 & 0.014 & 0.055 & 0.798 \\
\hline & & Item $8(\mathrm{y} 4)$ & 2 & 1 & 2.270 & 2.434 & -0.164 & 0.184 & 0.373 \\
\hline & \multirow{4}{*}{ Loading } & Item 3 (y1) & 2 & 1 & 0.542 & 0.529 & 0.013 & 0.075 & 0.866 \\
\hline & & Item 4 (y2) & 2 & 1 & 0.998 & 1.090 & -0.092 & 0.162 & 0.569 \\
\hline & & Item 5 (y3) & 2 & 1 & 1.041 & 0.820 & 0.222 & 0.174 & 0.203 \\
\hline & & Item 8 (y4) & 2 & 1 & 0.711 & 0.729 & -0.018 & 0.103 & 0.864 \\
\hline \multirow{10}{*}{ OGD } & \multirow{5}{*}{ Intercept } & Item 17 (y5) & 2 & 1 & 1.849 & 1.884 & -0.036 & 0.093 & 0.700 \\
\hline & & Item 18 (y6) & 2 & 1 & 2.207 & 2.336 & -0.129 & 0.168 & 0.443 \\
\hline & & Item 19 (y7) & 2 & 1 & 2.234 & 2.044 & 0.190 & 0.142 & 0.180 \\
\hline & & Item 20 (y8) & 2 & 1 & 1.544 & 1.517 & 0.027 & 0.048 & 0.574 \\
\hline & & Item 21 (y9) & 2 & 1 & 2.105 & 2.102 & 0.003 & 0.035 & 0.924 \\
\hline & \multirow{5}{*}{ Loading } & Item 17 (y5) & 2 & 1 & 0.578 & 0.587 & -0.009 & 0.082 & 0.915 \\
\hline & & Item 18 (y6) & 2 & 1 & 0.990 & 1.008 & -0.018 & 0.116 & 0.876 \\
\hline & & Item 19 (y7) & 2 & 1 & 1.117 & 1.062 & 0.055 & 0.136 & 0.687 \\
\hline & & Item 20 (y8) & 2 & 1 & 0.441 & 0.503 & -0.062 & 0.112 & 0.579 \\
\hline & & Item 21 (y9) & 2 & 1 & 1.082 & 0.754 & 0.328 & 0.167 & 0.050 \\
\hline
\end{tabular}


Table 8. Continues.

\begin{tabular}{|c|c|c|c|c|c|c|c|c|c|}
\hline \multirow{12}{*}{ IGG } & \multirow{6}{*}{ Intercept } & Item $22(\mathrm{y} 10)$ & 2 & 1 & 2.306 & 2.267 & 0.040 & 0.071 & 0.573 \\
\hline & & Item 25 (y11) & 2 & 1 & 2.552 & 2.561 & -0.009 & 0.057 & 0.876 \\
\hline & & Item 26 (y12) & 2 & 1 & 3.014 & 3.096 & -0.081 & 0.097 & 0.400 \\
\hline & & Item 27 (y13) & 2 & 1 & 2.855 & 3.057 & -0.202 & 0.183 & 0.267 \\
\hline & & Item 28 (y14) & 2 & 1 & 3.020 & 2.864 & 0.157 & 0.157 & 0.320 \\
\hline & & Item $29(\mathrm{y} 15)$ & 2 & 1 & 3.481 & 3.466 & 0.015 & 0.044 & 0.733 \\
\hline & \multirow{6}{*}{ Loading } & Item $22(\mathrm{y} 10)$ & 2 & 1 & 0.706 & 0.789 & -0.083 & 0.104 & 0.422 \\
\hline & & Item $25(\mathrm{y} 11)$ & 2 & 1 & 0.879 & 0.969 & -0.090 & 0.105 & 0.390 \\
\hline & & Item $26(\mathrm{y} 12)$ & 2 & 1 & 0.874 & 0.951 & -0.077 & 0.098 & 0.432 \\
\hline & & Item 27 (y13) & 2 & 1 & 0.962 & 0.810 & 0.151 & 0.137 & 0.271 \\
\hline & & Item $28(y 14)$ & 2 & 1 & 0.716 & 0.661 & 0.055 & 0.087 & 0.529 \\
\hline & & Item 29 (y15) & 2 & 1 & 0.684 & 0.564 & 0.120 & 0.131 & 0.360 \\
\hline \multirow{6}{*}{ SD } & \multirow{3}{*}{ Intercept } & Item $30(\mathrm{y} 16)$ & 2 & 1 & 0.526 & 0.482 & 0.044 & 0.433 & 0.919 \\
\hline & & Item 37 (y17) & 2 & 1 & 0.272 & 0.331 & -0.059 & 0.306 & 0.848 \\
\hline & & Item $38(\mathrm{y} 18)$ & 2 & 1 & 0.265 & 0.265 & 0.000 & 0.074 & 0.999 \\
\hline & \multirow{3}{*}{ Loading } & Item $30(\mathrm{y} 16)$ & 2 & 1 & 0.417 & 0.405 & 0.012 & 0.051 & 0.810 \\
\hline & & Item 37 (y17) & 2 & 1 & 0.542 & 0.526 & 0.016 & 0.066 & 0.811 \\
\hline & & Item $38(y 18)$ & 2 & 1 & 0.566 & 0.614 & -0.048 & 0.098 & 0.623 \\
\hline \multirow{8}{*}{$P$} & \multirow{4}{*}{ Intercept } & Item 42 (y19) & 2 & 1 & 1.205 & 1.208 & -0.004 & 0.009 & 0.671 \\
\hline & & Item $44(y 20)$ & 2 & 1 & 1.660 & 1.677 & -0.017 & 0.025 & 0.512 \\
\hline & & Item $46(\mathrm{y} 21)$ & 2 & 1 & 1.521 & 1.376 & 0.145 & 0.221 & 0.512 \\
\hline & & Item $47(\mathrm{y} 22)$ & 2 & 1 & 2.006 & 2.356 & -0.350 & 0.217 & 0.106 \\
\hline & \multirow{4}{*}{ Loading } & Item 42 (y19) & 2 & 1 & 0.243 & 0.542 & -0.299 & 0.116 & $0.010^{*}$ \\
\hline & & Item $44(y 20)$ & 2 & 1 & 0.882 & 0.835 & 0.047 & 0.174 & 0.788 \\
\hline & & Item $46(\mathrm{y} 21)$ & 2 & 1 & 0.805 & 0.862 & -0.057 & 0.173 & 0.740 \\
\hline & & Item $47(\mathrm{y} 22)$ & 2 & 1 & 0.416 & 0.395 & 0.021 & 0.102 & 0.841 \\
\hline \multirow{10}{*}{$\mathrm{S}$} & \multirow{5}{*}{ Intercept } & Item $48(\mathrm{y} 23)$ & 2 & 1 & 4.546 & 4.499 & 0.048 & 0.164 & 0.772 \\
\hline & & Item 49 (y24) & 2 & 1 & 4.142 & 4.191 & -0.049 & 0.190 & 0.796 \\
\hline & & Item $50(y 25)$ & 2 & 1 & 4.635 & 4.564 & 0.071 & 0.230 & 0.757 \\
\hline & & Item $51(\mathrm{y} 26)$ & 2 & 1 & 3.343 & 3.388 & -0.044 & 0.125 & 0.723 \\
\hline & & Item $52(\mathrm{y} 27)$ & 2 & 1 & 3.917 & 3.920 & -0.003 & 0.129 & 0.980 \\
\hline & \multirow{5}{*}{ Loading } & Item $48(y 23)$ & 2 & 1 & 0.681 & 0.594 & 0.087 & 0.180 & 0.628 \\
\hline & & Item $49(\mathrm{y} 24)$ & 2 & 1 & 0.848 & 0.697 & 0.151 & 0.209 & 0.470 \\
\hline & & Item $50(y 25)$ & 2 & 1 & 0.955 & 1.104 & -0.149 & 0.213 & 0.484 \\
\hline & & Item 51 (y26) & 2 & 1 & 0.582 & 0.702 & -0.120 & 0.179 & 0.503 \\
\hline & & Item 52 (y27) & 2 & 1 & 0.711 & 0.710 & 0.001 & 0.019 & 0.958 \\
\hline
\end{tabular}

${ }^{*} p<.05$

\subsection{Reliability}

The internal consistency reliability of the Union Bias Scale was examined with the Cronbach Alpha and the indicator reliability and the composite reliability coefficients. Table 9 shows the Cronbach's alpha, average variance, and composite reliability coefficients of the scale. When Table 9 is examined, it can be seen that the Cronbach alpha value of the scale is .81 for the in group favoritism dimension; .85 for the out group disdain dimension; .87 for the in group glorification dimension; .78 for the social distance dimension; .78 for the prejudices dimension, and .81 for the stereotypes dimension. Cronbach's alpha reliability of the whole scale is .89 . 
Composite reliability is above the limit value of .70 in each dimension and the whole scale (Hair et al., 2014). When the findings are evaluated together, it is seen that the reliability of the scale is also provided.

Table 9. Cronbach's Alpha, Mean Variance and Composite Reliability Coefficients of the Scale.

\begin{tabular}{lllll}
\hline \multirow{2}{*}{ Dimensions } & Cronbach Alpha & Mean Variance & $\begin{array}{l}\text { Composite } \\
\text { Reliability }\end{array}$ \\
\hline \multirow{2}{*}{ Whole Scale } & IGF & 0.81 & 0.54 & 0.82 \\
& DGK & 0.85 & 0.55 & 0.86 \\
& IGG & 0.87 & 0.53 & 0.87 \\
& SD & 0.78 & 0.57 & 0.79 \\
& P & 0.78 & 0.50 & 0.80 \\
& S & 0.81 & 0.48 & 0.82 \\
\hline
\end{tabular}

\section{DISCUSSION and CONCLUSION}

This study aimed to develop a reliable and valid scale on union bias and apply it in order to measure union bias. The union bias scale was constructed in the context of ingroup bias. The 27-items scale (see Appendix Table A) including only positive wordings was a 5-point Likerttype scale (ranging between extremely disagree, disagree, slightly agree, quite agree, and extremely agree). As a result of EFA, 27 items were grouped under six factors, whose eigenvalues were greater than 1.0. The scale's seven-factor structure accounted for $64.30 \%$ of the total variance. To determine the accuracy of the six-dimensional structure of the Union Bias Scale determined by EFA, first and second-order CFA was applied to the 27-item structure of the scale. It was also revealed that the scale has convergent validity, discrimination validity, and measurement invariance. Also, measurement invariance in gender groups was examined. The Cronbach Alpha and combined reliability coefficients were calculated to determine the scale's reliability. As a result of the first and second order confirmatory factor analysis, the scale's structure did not differ in gender groups. The Cronbach's alpha value was .90 and the composite reliability was .96 . The Cronbach alpha reliability and composite reliability of the union bias scale were found above 0.70 , which is the limit value, both in each dimension and in the entire scale. When the findings were evaluated together, it was demonstrated with different validity and reliability determination methods that the six-dimensional structure of the Union bias Scale consisting of 27 items is valid and reliable.

If unions enhance productivity, and if this productivity is economically crucial, the spread of unionism is essential (Doucouliagos et al., 2005). Understanding the unique identities of teachers' unions is possible by understanding the contexts in which the unions operate, understanding the relevant literature analysis (the concepts they refer to), and also understanding the dynamics within the union (Charlie, 2002). The effect of teacher unions on school output depends on the definition of unionization and its goals (Guthery, 2018). Therefore, it is possible to hear and see that different actions are taken even if the unions' objectives are the same or similar in theory. It can be said that teacher unions should focus on what they can do for teachers rather than what they can give to the government (or the political parties they are associated with) (Bağc1, 2009). Unions rely on active members to achieve their goals by participating in public meetings, strikes, civil disobedience, and political actions and defending union positions and policies in their schools (Popiel, 2013). Since an active member has a high union affiliation, the level of identification with his/her union is also high. People with a high level of identification with their groups are expected to exhibit higher levels of ingroup bias than others (Çoksan, 2016). This situation increases the impact of union bias in 
organizational environments. Those unions' engagement in political efforts rather than in the improvement of teachers' rights (Yalçın Durmuş, 2018) increases the grouping among teachers (Kara, 2016). The reflection of the unions on the school climate is felt negatively in inner group bias. One way to decrease the level of union bias at schools may be to have common goals of unions, organize common activities, and therefore encourage teachers to communicate with each other. As long as the tendency on politicization of unions goes down, it is expected that union bias as its reflection on the organizational environments also decreases. Politicians, practitioners, and researchers are also expected to find solutions to reduce such negative effects as well.

There are no scales for trade union bias in the literature. Although union bias is a stronger form of union affiliation, it does not contain a harmless sense of belonging such as union affiliation. Union bias includes meanings such as factionalism and partiality in Turkish and it refers to fanaticism that has more destructive consequences. Especially in organizational environments, it can have effects that deeply influence the organizational climate, communication climate, organizational justice, and organizational trust feelings. One way of understanding these negative effects caused by union bias was thought to require the presence of a measurement tool that measures union bias and this study was thought to overcome this deficiency.

Based on these comments, the following recommendations can be made:

1- The scale can be applied in schools, enterprises, and organizations employing workers due to its design as it is not limited to a certain institution and it includes general expressions; it can also be applied to employees who are members of different unions such as civil servant unions or trade unions.

2- The relationship of trade union bias with social identity or variables such as organizational climate, communication climate, organizational justice, organizational trust, and organizational cynicism can be investigated.

3- The scale can be applied to different union member teachers and their views can be compared.

4- Comparisons can be made by applying the scale at different levels of education.

5 - Since union bias is a phenomenon that is affected by the effectiveness of the union, the scale can be applied to employees with too many and too few members in certain regions or cities and comparisons can be made.

\section{Acknowledgments}

The study was presented as an abstract of paper in VI. International Eurasian Educational Research Congress / EJERCongress 2019.

\section{Declaration of Conflicting Interests and Ethics}

The authors declare no conflict of interest. This research study complies with research publishing ethics. The scientific and legal responsibility for manuscripts published in IJATE belongs to the author Ethics Committee Number: Düzce University, 17/09/2020 - 2020/181.

\section{Authorship Contribution Statement}

Ender Kazak: Investigation, Resources, Introduction, Methodology, Software, Analysis, Findings, Discussion, Supervision, and Validation, Writing original draft.

\section{ORCID}

Ender KAZAK (iD https://orcid.org/0000-0001-5761-6330

\section{REFERENCES}

Akyürek, S. (2016). Türkiye'de iç grup yanlılığının toplumsal adalete ve güvenliğe etkisi [The effect of ingroup bias on social justice and security in Turkey]. The Journal of Europe- 
Middle East Social Science Studies, 2(2), 161-179. https://dergipark.org.tr/tr/download/a rticle-file/174247

Allport, G. W. (1954). The nature of prejudice. Reading, MA: Addison Wesley.

Alpar, R. (2011). Çok değişkenli istatistiksel yöntemler [Multivariate statistical methods]. Detay Yayıncilik.

Arslan, C. (2015). Öğretmenlerin sendikal örgütlenmeye ilişkin tutumlarl ve sendikal örgütlenme nedenleri [Teachers' attitudes towards teachers unions and the reasons of their unionization]. [Unpublished master's thesis]. Cumhuriyet University.

Asparouhov, T., \& Muthén, B. (2014). Multiple-Group Factor Analysis Alignment. Structural Equation Modeling: A Multidisciplinary Journal, 21(4), 495-508.

Bağc1, A. (2009). Application of total quality management in teacher unions from the perspectives of union members [Unpublished master's thesis]. Middle East Technical University.

Bayar, L. S. (2015). The effect of belonging to a labour union on work values and work behaviours. [Unpublished Doctoral Dissertation]. Dokuz Eylül University.

Baydar, F. (2016). Analysis of teachers' opinions on the role of unions for constitution of educational policy. [Unpublished master's thesis]. Marmara University.

Baysal, Ö., \& Yücel, C. (2010). Elementary school teachers' attitudes toward unions: sample of Uşak Province. Educational Administration: Theory and Practice, 16(3), 329-352. https://dergipark.org.tr/tr/download/article-file/108220

Bentler, P. M., \& Bonett, D. G. (1980). Significance tests and goodness of fit in the analysis of covariance structures. Psychological Bulletin, 88(3), 588-606. https://doi.org/10.1037/00 $\underline{33-2909.88 .3 .588}$

Berkant, H. G., \& Gül, M. (2017). Union member teachers' perceptions and expectationstowards unions. Journal of the Human and Social Sciences Researches, 6(1), 419-442.

Brown, T. A. (2006). Confirmatory factor analysis for applied research. New York, NY: Guilford Press.

Büyüköztürk, Ş. (2002). Factor analysis: basic concepts and using to development scale. Educational Administration in Theory \& Practice, 8(4), 470-483. https://dergipark .org.tr/tr/download/article-file/108451

Büyüköztürk, S., Kılıç Çakmak, E., Akgün, O. E., Karadeniz, S., \& Demirel, F. (2011). Bilimsel araştırma yöntemleri [Scientific research methods]. 8. Bask1, Pegem Akademi Yayınları.

Büyüköztürk, Ş. (2006). Sosyal bilimler için veri analizi elkitabı: İstatistik, araştırma deseni, SPSS uygulamalarl ve yorum [Data analysis handbook for social sciences: Statistics, research design, SPSS applications and interpretation]. 6. Bask1, Pegem A. Yayınc1l1k.

Charlie, N. (2002). Reconciling teacher unionism's disparate identities: A View from the Field. BCTF Research Report. British Columbia Teachers' Federation, Vancouver.

Chou, C. P., \& Bentler, P. M. (1995). Estimation and tests in structural equation modeling. In R. H. Hoyle (Ed.), Structural equation modeling: Concepts, issues, and applications (pp. 37-55). Sage.

Çelik, G. (2011). Illköğretim okullarında örgütsel ayrımcılık ve ögrretmenlerin tükenmişlik 654 düzeylerine etkisi [Organizational discrimination in primary schools and its effects on teachers' burnout levels]. [Unpublished master's thesis]. Sakarya University.

Çimendağ, F. Ş. (2013). Yüksek ve düşük statülü gruplarda iç grup ve dış grup yanlılı̆̆ [Ingroup and out-group favouritism in high and low status groups]. [Unpublished master's thesis]. Mersin University. 
Çokluk, Ö., Şekercioğlu, G., \& Büyüköztürk, Ş. (2012). Sosyal bilimler için çok değişkenli istatistik: SPSS ve LISREL uygulamaları [Multivariate Statistics for Social Sciences: SPPS and LISREL Applications]. Pegem Academy Press.

Çoksan, S. (2016). Sosyal kimlik özdeşimi ve iç grup normunun iç grup yanlılı̆̆ ile ilişkisi [Social identity identification and the relationship of ingroup norm to ingroup bias] [Unpublished master's thesis]. Mersin University.

Çoksan, S. (2019). Causal attributions of in-group favoritism and equal allocation between in and out-group. Nesne, 7(14), 83-101. https://doi.org/10.7816/nesne-07-14-06

Çuhadar Gürkaynak, E. Ç. (2012). Toplumsal temas: Önyargl ve ayrımcılı̆̆ önlemek için bir sosyal değişim aract olarak kullantlabilir mi? [Social contact: Can it be used as a tool for social change to avoid prejudice and discrimination?] Çayır, K. \& Ceyhan, M. A. (derl.), Ayrımcllık çok boyutlu yaklaşımlar [Multidimensional approaches to discrimination] (255-265). İstanbul Bilgi Üniversitesi Yayınları.

Demir, F. (2013). Sendikaların kuruluşu ve işleyişi. [Establishment and functioning of trade unions]. Çalışma ve Toplum, 4, 17-42.

Doucouliagos, H., Laroche, P., \& Stanley, T. (2005). Publication Bias in Union-Productivity Research? Relations industrielles/Industrial Relations, 60(2), 320-347. https://doi.org/10.7202/011724ar

Dovidio, J. F., Love, A., Schellhaas, F. M. H., \& Hewstone, M. (2017). Reducing intergroup bias through intergroup contact: Twenty years of progress and future directions. Group Processes \& Intergroup Relations, 20(5), 606-620.

Eraslan, L. (2012). Evaluation of today's teacher unionism. 21. Yüzyllda Eğitim ve Toplum, 1(1), 59-72. https://dergipark.org.tr/tr/download/article-file/59603

Erdem M., \& Meriç, E. (2012). Study on scale development about favoritism at school administration. Journal of Educational Sciences Research, 2(2), 141-154. https://dergipa rk.org.tr/tr/download/article-file/697379

Erdem M., \& Meriç, E. (2013). According to the perceptions of primary school teachers favoritism on school management. Educational Administration: Theory and Practice, 19(3), 467-498. https://dergipark.org.tr/tr/download/article-file/108150

Fornell, C., \& Larcker, D. F. (1981). Evaluating structural equation models with unobservable variables and measurement error. Journal of Marketing Research, 18, 39-50.

Göregenli, M. (2012). Temel kavramlar: Önyargl, kalıpyargl ve ayrımcılık [Basic concepts: Prejudice, stereotype and discrimination]. Çayır, K. \& Ceyhan, M. A. (derl.), Ayrımcılık çok boyutlu yaklaşımlar [Multidimensional approaches to discrimination], İstanbul Bilgi Üniversitesi Yayınları.

Guthery, S. (2018). The influence of teacher unionization on educational outcomes: A summarization of the research, Popular methodologies and gaps in the literature. The William \& Mary Educational Review, 5(1), 124-136.

Güneş, H. (2013). Sendikal haklar ve ülkemizde kamu görevlileri sendikacılığının gelişimi [Right to unionization and development of public servants trade unionism in Turkey]. ÇSGB Çalışma Dünyası Dergisi [Labour World], 1(1), 62-79.

Hair, J. F., Black, W. C., Babin, B. J., \& Anderson, R. E. (2009). Multivariate data analysis (7th ed.). Pearson Prentice Hall.

Hair, J. Hult, GTM. Ringle, C., \& Sarstedt M. (2014). A Primer on Partial Least Squares Structural Equation Modeling (PLS-SEM) (SAGE Publications, Incorporated).

Hasta, D., \& Arslantürk, G. (2013). Polislik mesleğine yönelik iç-grup yanlılı̆̆1 ve tutumlar [Ingroup bias and attitudes towards the policing profession]. Türk Psikoloji Yazıları, 16(31), 60-70. https://www.psikolog.org.tr/tr/yayinlar/dergiler/1031828/tpy1301996120 130000m000094.pdf 
Hooper, D., Coughlan, J., \& Mullen, M. (2008). Evaluating model fit: A synthesis of the structural equation modelling literature. In 7th European Conference on research methodology for business and management studies (pp. 195-200).

Joreskog, K.G. (1999). How large can a standardized coefficient be. Unplublished report. SSI Central, Inc. http://www.statmodel.com/download/Joreskog.pdf

Kağıtçıbaşı, Ç. (2008). Günümüzde insan ve Insanlar Sosyal Psikolojiye Giriş [Man and People Today. Introduction to Social Psychology]. 11. Basım, Evrim Yayınevi.

Kalaycı, Ş. (2010). SPSS uygulamalı çok değişkenli istatistik teknikleri [SPSS applied multivariate statistical techniques] (Vol. 5). Ankara, Turkey: Asil Yayın Dağıtım.

Kara, M. (2016). The reasons why teachers do not affiliate to unions and their expectations from them. The Journal of Academic Social Science, 4(22), 423-440.

Karaman, H. G., \& Erdoğan, Ç. (2016). An investigation of the education unions in Turkey: goals, expectations and problems. Sakarya University Journal of Education, 6(2), 123 140. https://dergipark.org.tr/tr/download/article-file/227590

Kayıkçı, K. (2013). Unionization in the public and education sector in Turkey, and Expectations of School administrators and teachers expectations from unions. Amme Ídaresi Dergisi, 46(1), 99-126.

Keskinkılıç-Kara, (2016). Individual and organizational effects of political orientation discrimination on teachers in schools. Kastamonu Eğitim Dergisi, 24(3), 1371-1384. https://dergipark.org.tr/tr/download/article-file/210080

Keskinkılıç-Kara, S. B., \& Oğuz, E. (2016). Relationship between political discrimination level perceived by teachers and teachers' organizational cynicism levels. Eurasian Journal of Educational Research, 63, 55-70.

Kline, P. (1994). An Easy Guide to Factor Analysis. Routledge.

Kline, T. J. (2005). Psychological testing: A practical approach to design and evaluation. Sage Publications.

Kostakoğlu, G. (2010). Grup kimliğine yönelik tehdit ile iç-grup yanlılı̆̆ının benlik değeri üzerindeki etkileri [The Effects of Threat to Group Identity and In-Group Bias on SelfEsteem] [Unpublished master's thesis]. Hacettepe University.

Küçükkömürler, S., \& Sakall1-Uğurlu, N. (2017). Social contact theories to regulate intergroup relations: intergroup, extended, imagined contact. Nesne Psikoloji Dergisi (NPD), 5(9), 1-31. https://www.nesnedergisi.com/makale/pdf/1466592418.pdf

Mert, Ö. (2013). Organization activities and intellectual actions of teachers in Turkey(19601980) [Unpublished Doctoral Dissertation]. Süleyman Demirel University.

Mertler, C. A., \& Vannatta, R. A. (2005). Advanced and multivariate statistical methods: Practical application and interpretation, (3rd ed.). Edition Taylor \& Francis.

Myers, D. G. (2015). Sosyal Psikoloji [Social Psychology]. Onuncu basımdan çeviri, Nobel.

Nunnally, J., \& Bernstein, I. (1994). Psychometric Theory. (3rd ed.). McGraw Hill.

Özkiraz, A., \& Talu, N. (2008). Emergence of trade-unions: comparison between Turkey and Western European Countries. Sosyal Bilimler Araştırmalart Dergisi. 2, 108-126. https://dergipark.org.tr/tr/download/article-file/801854

Pettigrew, T. F., \& Tropp, L. R. (2006). Interpersonal relations and group processes A metaanalytic test of intergroup contact theory. Journal of Personality and Social Psychology, 90(5), 751-783.

Pettigrew, T. F. (2016). In pursuit of three theories: Authoritarianism, relative deprivation, and intergroup contact. Annual Review of Psychology, 67, 1-21.

Polat, S., \& Kazak, E. (2014). The correlation between school principals' favoritist behaviors and attitudes and teachers' perception of organizational justice. Educational Administration: Theory and Practice, 20(1), 71-92. https://dergipark.org.tr/tr/download/ $\underline{\text { article-file/108137 }}$ 
Polat, S., \& Hiçyılmaz, G. (2017). Discrimination behaviors that classroom teachers are exposed and the causes of these behaviors. Journal of Qualitative Research in Education, 5(2), 47-66. http://enadonline.com/public/assets/catalogs/0838411001544185376.pdf

Popiel, K. (2013). Teacher union legitimacy: Shifting the moral center for member engagement. JEduc Change, 14, 465-500.

Schermelleh-Engel, K., Moosbrugger, H., \& Müller, H. (2003). Evaluating the fit of structural equation models: Tests of significance and descriptive goodness-of-fit measures. Methods of Psychological Research Online, 8(2), 23-74.

Seat, A. A., Joyce, N., Harwood, J., \& Arroyo, A. (2015). Necessary and sufficient conditions for positive intergroup contact: A fuzzy set qualitative comparative analysis approach to understanding intergroup attitudes. Communication Quarterly, 63(2), 135-155.

Seçer, B. (2009). The effect of women's union attitudes and perceived gender discrimination on the willingness to join a union. Çalışma ve Toplum, 4, 27-60. https://calismatoplum.o $\mathrm{rg} /$ Content/pdf/calisma-toplum-1317-fcee87fe.pdf

Sokolov, B. (2019). Sensitivity of Goodness of Fit Indices to Lack of Measurement Invariance with Categorical Indicators and Many Groups. Higher School of Economics Research Paper No. WP BRP, 86.

Sürekli, D. (1998). Kimya sektörüne bă̆lı bir sendikada sendikaya bă̆lllık ve sendikal faaliyetlere katılım arasindaki ilişkinin incelenmesi [Investigation of the relationship between union commitment and participation in union activities in a union affiliated to the chemical industry] [Unpublished Doctoral Dissertation]. Marmara University.

Tabachnick, B. G., \& Fidell, L. S. (2007). Using Multivariate Statistics. Person Education Inc. Tajfel, H., Billig, M., Bundy, R. P., \& Flament, C. (1971). Social categorization and intergroup behavior. European Journal of Social Psychology, 1, 149-177. https://doi.org/10.1002/ej sp.2420010202

Tavşanc1l, E. (2014). Tutumların ölçülmesi ve SPSS ile veri analizi [Measuring attitudes and data analysis with SPSS]. (5.basim). Nobel Yayınc1l1k.

Taylor, S. E., Peplau, L. A., \& Sears, D. O. (2007). Sosyal Psikolojiye Giriş [Introduction to Social Psychology]. (1. Bask1). Çev.: Ali Dönmez, İmge Kitabevi Yayınları.

TDK. Güncel Türkçe Sözlük [Current Turkish Dictionary]. www.tdk.gov.tr (Erişim tarihi: 20 Eylül 2019).

Tucker, L. R., \& Lewis, C. (1973). A reliability coefficient for maximum likelihood factor analysis. Psychometrika, 38(1), 1-10. https://doi.org/10.1007/BF02291170

Uyumaz, G., \& Çokluk, Ö. (2016). An investigation of item order and rating differences in likert-type scales in terms of psychometric properties and attitudes of respondents. Journal of Theoretical Educational Science, 9(3), 400-425. https://dergipark.org.tr/tr/do wnload/article-file/304330

Uyumaz, G., \& Sirganc1, G. (2020). What is the required sample size for confirmatory factor analysis?: Bayesian Approach and maximum likelihood estimation. International Journal of Society Researches, 16(32), 5302-5340. https://dergipark.org.tr/tr/download/articlefile/1400546

Widaman, K. F., \& Reise, S. P. (1997). Exploring the measurement invariance of psychological instruments: Applications in the substance use domain. In K. J. Bryant, M. Windle, \& S. G. West (Eds.), The science of prevention: Methodological advances from alcohol and substance abuse research (p. 281-324). American Psychological Association. https://doi.org/10.1037/10222-009

Yalçın Durmuş, G. (2018). Öğretmenlerin sendikal örgütlenmelerinin okulda karar verme ve iletişim süreçleriyle ilişkisinin analizi [Analysis of the correlation between unionization of teachers and decision making and communication processes at the school] [Unpublished Doctoral Dissertation]. Inönü University. 
Yurdigül, Y., \& İspir, N. (2015). Ötekinin inşa edildiği sorunlu bir alan olarak Oscar ödül törenleri (85. Akademi Ödülleri ve "Argo" Filmi Örneği) [Other being built, as a problem area: Oscar award ceremonies (85th Academy Awards and the "Argo" Movie Example)]. 1. Ulusal Toplumsal ve Kurumsal Çatışmalar/Çözümler Kongresi. Bildiriler Kitabı, Düzce Üniversitesi Gölyaka Meslek Yüksekokulu, Düzce. 


\section{APPENDIX}

Table A displays the 27 items of standardized English and Turkish version of Union Bias Scale.

Table A. Union Bias Scale (Standardized English and Turkish version)

\begin{tabular}{|c|c|c|c|c|c|c|}
\hline \multicolumn{2}{|r|}{$\begin{array}{l}\text { Bu ölçek, sendikal yanlılığı belirlemeye yönelik maddelerden oluşmaktadır. } \\
\text { Maddelerin her birini okuyarak, "Hiç Katılmıorum, Katılmıyorum, Çok Az } \\
\text { Katıllyorum, Oldukça Katıllyorum, Tamamen Katılıyorum" seçeneklerinden } \\
\text { birini işaretleyiniz. Maddelerin tümünü içtenlikle işaretlemeniz araştırma } \\
\text { sonuçları açısından oldukça önemlidir. Teşekkür ederim. }\end{array}$} & 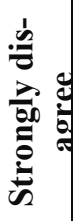 & 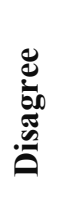 & 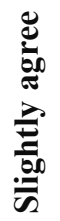 & 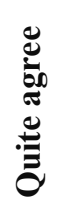 & \\
\hline \multirow{4}{*}{ 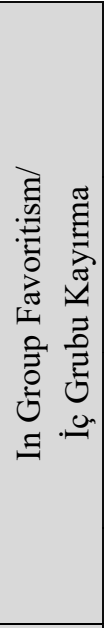 } & $\begin{array}{l}\text { 1. People from my own union always take precedence over those } \\
\text { from other unions. } \\
\text { 1. Kendi sendikamdan olanlar, her zaman diğer sendikalardan } \\
\text { olanlardan önce gelir. }\end{array}$ & (1) & (2) & (3) & (4) & (5) \\
\hline & $\begin{array}{l}\text { 2. It makes me happy that someone from my union is chosen to dis- } \\
\text { tribute the tasks. } \\
\text { 2. Görevlerin dağıtımında kendi sendikamdan olan birinin seçilmesi } \\
\text { beni mutlu eder. }\end{array}$ & (1) & (2) & (3) & (4) & (5) \\
\hline & $\begin{array}{l}\text { 3. It makes me happy that someone from my union is chosen to dis- } \\
\text { tribute the awards. } \\
\text { 3. Ödüllerin dağıtımında kendi sendikamdan olan birinin seçilmesi } \\
\text { beni mutlu eder. }\end{array}$ & (1) & (2) & (3) & (4) & (5) \\
\hline & $\begin{array}{l}\text { 4. I prefer to work with a manager from my own union. } \\
\text { 4. Kendi sendikamdan olan bir yöneticiyle çalışmayı tercih ederim. }\end{array}$ & (1) & (2) & (3) & (4) & (5) \\
\hline \multirow{5}{*}{ 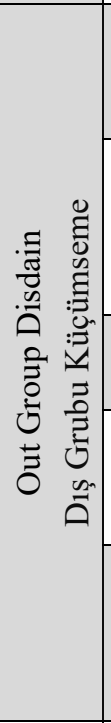 } & $\begin{array}{l}\text { 5. The activities of other unions are very ineffective and weak. } \\
\text { 5. Diğer sendikalardan olanların faaliyetleri oldukça etkisiz ve } \\
\text { zayıftır. }\end{array}$ & (1) & (2) & (3) & (4) & (5) \\
\hline & $\begin{array}{l}\text { 6. The ideological approaches of other unions cause an atmosphere of } \\
\text { unrest. } \\
\text { 6. Diğer sendikaların ideolojik yaklaşımları huzursuzluk ortamına } \\
\text { sebep olmaktadır. }\end{array}$ & (1) & (2) & (3) & (4) & (5) \\
\hline & $\begin{array}{l}\text { 7. The activities of other unions are segregating for employees. } \\
\text { 7. Diğer sendikaların faaliyetleri, çalışanları ayrıştırıcıdır. }\end{array}$ & (1) & (2) & (3) & (4) & (5) \\
\hline & $\begin{array}{l}\text { 8. Those from other unions cause conflicts in our institution. } \\
\text { 8. Diğer sendikalardan olanlar kurumumuzda çatı̧̧ma ortamına sebep } \\
\text { olmaktadır. }\end{array}$ & (1) & (2) & (3) & (4) & (5) \\
\hline & $\begin{array}{l}\text { 9. Those from other unions serve ideological purposes rather than un- } \\
\text { ion goals. } \\
\text { 9. Diğer sendikalardan olanlar, sendikal amaçlardan çok ideolojik } \\
\text { amaçlara hizmet etmekteler. }\end{array}$ & (1) & (2) & (3) & (4) & (5) \\
\hline \multirow{5}{*}{ 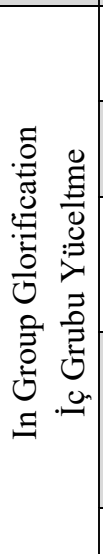 } & $\begin{array}{l}\text { 10. The union I am a member of is unique. } \\
\text { 10. Üyesi olduğum sendika eşsizdir. }\end{array}$ & (1) & (2) & (3) & (4) & (5) \\
\hline & $\begin{array}{l}\text { 11. The union I am a member of always makes the best decisions. } \\
\text { 11. Üyesi olduğum sendika her zaman en iyi kararları alır. }\end{array}$ & (1) & (2) & (3) & (4) & (5) \\
\hline & $\begin{array}{l}\text { 12. The union I am a member of is the one that defends our rights } \\
\text { most effectively. } \\
\text { 12. Üyesi olduğum sendika, haklarımızı en etkili savunan sendikadır. }\end{array}$ & (1) & (2) & (3) & (4) & (5) \\
\hline & $\begin{array}{l}\text { 13. The aims of the union I am a member of are higher than the aims } \\
\text { of other unions. } \\
\text { 13. Üyesi olduğum sendikanın amaçları diğer sendikaların } \\
\text { amaçlarından yüksektir. }\end{array}$ & (1) & (2) & (3) & (4) & (5) \\
\hline & 14. The union I am a member of is not a supporter of a political party. & (1) & (2) & (3) & (4) & (5) \\
\hline
\end{tabular}




\begin{tabular}{|c|c|c|c|c|c|c|}
\hline & 14. Üyesi olduğum sendika bir siyasi partinin arka bahçesi değildir. & & & & & \\
\hline & $\begin{array}{l}\text { 15. The activities of the union that I am a member of are unifying the } \\
\text { employees. } \\
\text { 15. Üyesi olduğum sendikanın faaliyetleri çalışanları birleştiricidir. }\end{array}$ & (1) & (2) & (3) & (4) & (5) \\
\hline \multirow{3}{*}{ 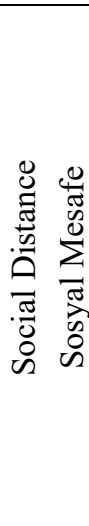 } & $\begin{array}{l}\text { 16. At my institution, my relations with employees from other unions } \\
\text { are not good. } \\
\text { 16. Kurumumda, diğer sendikalardan olan çalışanlarla ilişkilerim } \\
\text { soğuktur. }\end{array}$ & (1) & (2) & (3) & (4) & (5) \\
\hline & $\begin{array}{l}\text { 17. In my institution, my professional communication with employ- } \\
\text { ees from other unions is poor. } \\
\text { 17. Kurumumda, diğer sendikalardan olan çalışanlarla mesleki } \\
\text { iletişimim zayıftır. }\end{array}$ & (1) & (2) & (3) & (4) & (5) \\
\hline & $\begin{array}{l}\text { 18. In my institution, I have poor social communication with employ- } \\
\text { ees from other unions. } \\
\text { 18. Kurumumda, diğer sendikalardan olan çalışanlarla sosyal } \\
\text { iletişimim zayıftır. }\end{array}$ & (1) & (2) & (3) & (4) & (5) \\
\hline \multirow{4}{*}{ 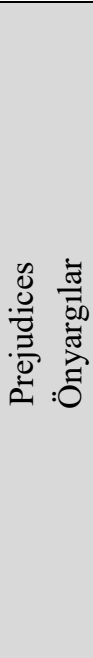 } & $\begin{array}{l}\text { 19. Those from other unions have a grudge and hatred towards me/us. } \\
\text { 19. Diğer sendikalardan olanlar bana/bize karşı kin ve nefret } \\
\text { içindedirler. }\end{array}$ & (1) & (2) & (3) & (4) & (5) \\
\hline & $\begin{array}{l}\text { 20. Although it is in favor of the employees, those from the other un- } \\
\text { ion do not support our union activities. } \\
\text { 20. Çalışanların lehine olsa da diğer sendikadan olanlar sendikal } \\
\text { faaliyetlerimizi desteklemezler. }\end{array}$ & (1) & (2) & (3) & (4) & (5) \\
\hline & $\begin{array}{l}\text { 21. It is not possible for those from other unions to cooperate with } \\
\text { us on union matters. } \\
\text { 21. Diğer sendikalardan olanların sendikal konularda bizimle } \\
\text { işbirliği yapması mümkün değildir. }\end{array}$ & (1) & (2) & (3) & (4) & (5) \\
\hline & $\begin{array}{l}\text { 22. It is not possible for all unions to unite around the same union } \\
\text { goals. } \\
\text { 22. Tüm sendikaların aynı sendikal amaçlar etrafında birleşmesi } \\
\text { mümkün değildir. }\end{array}$ & (1) & (2) & (3) & (4) & (5) \\
\hline \multirow{5}{*}{ 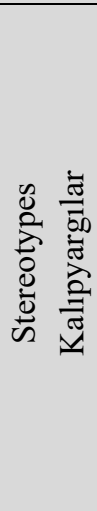 } & $\begin{array}{l}\text { 23. Among other unions there are unions that support the government } \\
\text { in power. } \\
\text { 23. Diğer sendikalar arasında "Iktidar yanlısı sendika" vardır. }\end{array}$ & (1) & (2) & (3) & (4) & (5) \\
\hline & $\begin{array}{l}\text { 24. Among other unions there are pro-terror unions. } \\
\text { 24. Diğer sendikalar arasında "Terör yanlısı sendika" vardır. }\end{array}$ & (1) & (2) & (3) & (4) & (5) \\
\hline & $\begin{array}{l}\text { 25. Among other unions there are nationalist unions. } \\
\text { 25. Diğer sendikalar arasında "Ulusalcı sendika" vardır. }\end{array}$ & (1) & (2) & (3) & (4) & (5) \\
\hline & $\begin{array}{l}\text { 26. Among other unions there are fascist unions. } \\
\text { 26. Diğer sendikalar arasında "Faşist sendika" vardır. }\end{array}$ & (1) & (2) & (3) & (4) & (5) \\
\hline & $\begin{array}{l}\text { 27. Among other unions there are collaborator unions. } \\
\text { 27. Diğer sendikalar arasında "İșbirlikçi sendika" vardır. }\end{array}$ & (1) & (2) & (3) & (4) & (5) \\
\hline
\end{tabular}

